\title{
Effect of water scarcity on households' livelihoods in Iwoye-Ketu Area of Ogun State, Nigeria
}

\author{
Adetayo K. AROMOLARAN ${ }^{1)}$ ABCDE $₫$, Ibiyinka O. ADEMILUYI ${ }^{2)}$ ACDF, \\ Abiodun E. SOTOLA ${ }^{\text {3) ADEF }}$, Felicia I. WOLE-ALO ${ }^{4) \text { BEF, }}$ \\ Oluwadamilola A. AROMIWURA ${ }^{\text {5) BEF}}$, Olubukola E. OGUNSUYI ${ }^{\text {() BEF }}$
}

1) orcid.org/0000-0003-2893-6559; Federal University of Agriculture Abeokuta, Department of Agricultural Extension and Rural Development, PMB 22, 110001, Abeokuta, Nigeria; e-mail: garomolaran@yahoo.com

2) orcid.org/0000-0003-2291-2804; College of Forestry, Jos, Nigeria; e-mail: bukkyinkus@yahoo.com

3) orcid.org/0000-0002-8701-2973; Federal University of Technology, Akure, Nigeria; e-mail: ask4emmab2013@gmail.com

4) orcid.org/0000-0001-7707-4516; Federal University of Technology, Akure, Nigeria; e-mail: fellymee@yahoo.com

5) orcid.org/0000-0002-4247-0831; Federal University of Agriculture Abeokuta, Department of Agricultural Extension and Rural Development, Abeokuta, Nigeria; e-mail: aromiwura.oluwadamilola@yahoo.com

6) orcid.org/0000-0001-9435-312X; Federal University of Agriculture Abeokuta, Department of Agricultural Extension and Rural

Development, Abeokuta, Nigeria; e-mail: suyiolubukola@gmail.com

For citation: $\quad$ Aromolaran A.K., Ademiluyi I.O., Sotola A.E., Wole-Alo F.I., Aromiwura O.A., Ogunsuyi O.E. 2019. Effect of water scarcity on households' livelihoods in Iwoye-Ketu Area of Ogun State, Nigeria. Journal of Water and Land Development. No. 43 (X-XII) p. 9-18. DOI: 10.2478/jwld-2019-0058.

\begin{abstract}
Water is an essential commodity which affects life and livelihoods in the universe. This study examined perceived effect of water scarcity on livelihoods in Iwoye-Ketu, Ogun State. Random sampling was used to select 80 rural households and water samples for the study. Data collected were analysed using descriptive, inferential and laboratory analyses. Findings showed that the mean age of respondents was 38 years with an average household size of four persons. The major sources of water were boreholes $(97.5 \%)$ and rainwater $(90.0 \%)$, the average trekking time to the water source was 24 minutes and the households requires an average of 162 litres of water per day. Water analysis' result showed that the water has $\mathrm{pH}(6.87)$, total dissolved solids $\left(0.175 \mathrm{mg} \cdot \mathrm{dm}^{-3}\right)$, temperature $\left(29.9^{\circ} \mathrm{C}\right)$ and turbidity $(0.6 \mathrm{FTU})$. The major causes of water scarcity include insufficient rainfall $(97.5 \%)$, increased sunlight intensity $(97.5 \%)$, pollution of water sources $(95.0 \%)$ and increased population (93.8\%). About $60 \%$ of them perceived water scarcity to have a negative effect on their livelihoods. Correlation analysis shows that there is a significant relationship between usage of water $(r=0.370, p<0.01)$ and perceived effect of water scarcity. It was concluded that water available for household use is not sufficient, although it is safe but contain some elements which are not of World Health Organization standard for good potable water. It is recommended that the community should build a hub for water collection and distribution close to the village centre and the government should provide water infrastructures to increase the supply of potable water.
\end{abstract}

Key words: Iwoye-Ketu, livelihoods, perceived effects, water quality analysis, water scarcity, water sources

\section{INTRODUCTION}

Water is a very important natural resource which is essential for life and good health. Water covers $70 \%$ of the Earth's surface, but only $3 \%$ of this is fresh water, of this only $1 \%$ is usable in rivers, lakes and subsoil aquifers [BHARUCHA 2005]. According to BARRETO [2008], the world contains an estimate of $1400 \mathrm{mln} \mathrm{km}^{3}$ of water, but only $0.003 \%$ which is not easily accessible can be utilized for drinking, hygiene, agriculture and industry. Water is 
a contributing element to the body; the body system cannot survive for more than a few days without it. The body demands safe fresh water for survival. Water scarcity refers to the volumetric abundance or lack/inadequate water supply; it is calculated as a ratio of human water consumption to available water supply in a given area [ORR, PEGRAM 2014]. Lack of water to meet daily needs is a reality today for one in three people around the world [MUTA'AHELLANDENDU 2012]. Water is not only a vital environmental element for all forms of life, but has a great role its plays in socio-economic development of human populace. Globally, as the population grows, the need for water in both cities and rural areas get worse. The scarcity of water does not only affect the households but also the agricultural and industrial activities. The water scarcity requires urgent attention and incessant actions to tackle the problem. World Health Organisation reported that over 80 countries of the world now have a water shortage and this is reflecting through their health and economies [WHO 2003]. It is also said that an estimate of about 1.2 billion people lacks access to safe and affordable water for their domestic use [GRANT et al. 2012].

Water scarcity affects all spheres of life and threatens the sustainability of the natural resources base. In addressing water scarcity, an intersectional and multidisciplinary approach is required to manage water resources in a sustainable manner that will not affect the ecosystems, economic and social wellbeing of the people. Also, enhancing water productivity (the volume of production per unit of water) in all sectors is paramount to successful programs of water scarcity alleviation [STEDUTO et al. 2012]. Nigeria is the eighth most populous countries in the world and has begun grappling with issues of water scarcity across a number of her states forcing infrastructure and long term sustainability problem [MUTA'AHELLANDENDU 2012].

The water scarcity issue is considerably daunting, given that Nigeria has a total population of over 152 million people and less than $30 \%$ have access to adequate drinking water [KREBS 2010]. Shortage of water contributes to poverty, cause social hardship and impede development. According to Integrated Regional Information Networks, 62\% of the population of Nigeria has access to improved water sources [IRIN 2007]. Nevertheless, it is having access to the available water that creates the water-related impact on human well-being. The three main dimensions that characterize water scarcity are a physical lack of water availability to satisfy demand; the level of infrastructure development that controls storage, distribution and access; and the institutional capacity to provide the necessary water services [FAO 2012b].

MAFINISEBI [2002] opined that convenient sources of safe water are of enormous importance to improve human health, agricultural labour productivity, hence income generation by rural households. GHOLAMREZAI and SEPAHVAND [2017] opined that one of the main challenges of water scarcity is the water consumption in the agriculture sector, it is necessary to optimize water consumption and apply optimal management of water in the agriculture sector. People, especially in the rural communities, seek water needed for their livelihoods and domestic use from far sources and the quality trekking time spent to the distant water sources could have been used in other activities for the benefit of the households. Inadequate access to improve water supply made the rural households to be vulnerable and it exposes them to certain challenges which could be that of health, economic, social and cultural issues. In Nigeria, many of the rural areas are faced with water scarcity and the households in the communities rely on self-water supply for both domestic, irrigation and livelihood purposes. The water scarcity does not only affect the households' domestic use but it also has an impact on their livelihoods. The output of the livelihoods can be affected directly or indirectly, even the cost of water as an input can increase the running cost of the livelihoods enterprise due to the water scarcity. In this view, it is imperative to examine effect of the water scarcity on the livelihoods by the rural households in the study area. This study was therefore guided by the following objectives:

- identify the available water sources in the study area;

- examine the accessibility of the water sources and its procurement;

- determine the quality of water sources and the quantity of water used;

- examine the level of utilization of the available water;

- identify the causes of water scarcity in the study area;

- ascertain perceived effect of water scarcity on households' livelihoods.

The study also tested the hypothesis that there is no significant relationship between the level of water utilization and the perceived effect of water scarcity on the rural household's livelihoods.

\section{STUDY METHODS}

\section{STUDY AREA}

The study was conducted in Iwoye-Ketu community, which is located in Imeko-Afon of Ogun State, Nigeria. Iwoye-Ketu shares boundaries with the Republic of Benin. The ethnic groups in the Iwoye-Ketu include Yoruba, Igbo, Hausa, Fulani and Igede. The coordinates of Iwoye-Ketu is $7^{\circ} 33^{\prime} 24^{\prime \prime} \mathrm{N}, 2^{\circ} 44^{\prime} 59^{\prime \prime} \mathrm{E}$ and it is about $100 \mathrm{~km}$ from Abeokuta the capital of Ogun state. The population of IwoyeKetu was 25,000 as at 2006 and is estimated to have increased to about 80,000 people in 2017 and land area is about $160,000 \mathrm{~km}^{2}$ [NPC 2006]. The rainfall pattern in the study area reaches a peak in July and September each year. The farming, hunting, trading and transportation activities around the border are the major occupation in the study area. The place is also known for cotton production and other food crops. Iwoye-Ketu holds several traditional beliefs among which are these taboos that forbid the use of umbrella and rearing of pigs. The town has few streams and no major river which dried up during the dry season, the town water level is very low that most wells did not have water and boreholes are not functioning well. The households in the community rely on the rainwater which they harvested into the ground tanks for their livelihoods and domestic uses. This approach of water supply is not sustainable and that makes the study area the right location for the study. 


\section{SAMPLING AND DATA COLLECTION}

The target population for the study are the rural households in Iwoye-Ketu community of Ogun state. Multi-stage random sampling was used to select the respondents. Iwoye-Ketu was purposively selected due to the observed prevalence of water scarcity in the area. Four villages were therefore selected using simple random sampling. From the frame of the list of households in each, the four selected villages, a proportional random selection of $5 \%$ of the households were chosen which were 20 households to make up of 80 households and the households' heads were sampled for the study. The total sample size for the study was 80 households. Data were collected through the use of an interview schedule for the study. Water samples were also obtained from each of the various water sources at different spot with the selected communities.

\section{DATA ANALYSIS}

Data were analysed using descriptive statistics such as percentages, mean, frequency distribution to encapsulate the variables while Pearson Products Moment Correlation (PPMC) was used to test the relationship between the level of utilization of water and perceived effect of water scarcity. Water quality analysis was also conducted to determine the following parameters $\mathrm{pH}$, electrical conductivity $\left(\mu \mathrm{S} \cdot \mathrm{cm}^{-1}\right)$, nitrate $\left(\mathrm{mg} \cdot \mathrm{dm}^{3}\right)$, chlorine $\left(\mathrm{mg} \cdot \mathrm{dm}^{3}\right)$, magnesium $\left(\mathrm{mg} \cdot \mathrm{dm}^{3}\right)$, sulphate $\left(\mathrm{mg} \cdot \mathrm{dm}^{3}\right)$, iron $\left(\mathrm{mg} \cdot \mathrm{dm}^{3}\right)$, temperature $\left({ }^{\circ} \mathrm{C}\right)$, turbidity and so on. The results were compared with the standard of quality water by World Health Organization.

\section{RESULTS AND DISCUSSION}

\section{DESCRIPTIVE STATISTICS OF THE RURAL HOUSEHOLDS}

Entries in Table 1 show that more than half (53.8\%) of the respondents were male and the mean age was 38 years. This implies that most of the rural households' head in the study area are youths and energetic, and as the head of the household they tend to provide the need of the household. This concurs with SMIT [2002] and ELSON [2012] which opine that the main role for men traditionally is the one of primary income-earner and breadwinner in the family. The respondents have access to formal education, 30\% had primary and $36.2 \%$ had secondary education, which is one of the reasons that people in the rural communities migrate to cities either to seek further education or employment. The basic education could also enlighten the people on water characteristics and the rudiments of water treatments. Those that are educated are will be more cautious about the sources of available water, hygiene and guide to be taken to make the water safe for use.

The average household size was 4 persons and the highest proportion $(77.5 \%)$ of the households had between 1 and 5 persons. This is line with the findings of OTUFALE and COSTER [2012] that the average household size in Ogun state was 7 persons and IRIN [2007] opined that
Table 1. Socio-economic characteristics of the rural households

\begin{tabular}{|l|c|c|c|}
\hline \multicolumn{1}{|c|}{ Variables } & $\begin{array}{c}\text { Frequency } \\
\text { (numbers) }\end{array}$ & Percentage & Mean \\
\hline Sex & & & \\
\hline- male & 43 & 53.8 & \\
\hline- female & 37 & 46.2 & \\
\hline Age (years) & 44 & 55.0 & \\
\hline$-<36$ & 25 & 31.2 & \\
\hline$-36-50$ & 11 & 13.8 & \\
\hline$->52$ & & & \\
\hline Marital status & 15 & 18.8 & \\
\hline - single & 65 & 81.2 & \\
\hline- married & & & \\
\hline Religion & 59 & 73.8 & \\
\hline- christianity & 20 & 25.0 & \\
\hline- islam & 1 & 1.2 & \\
\hline- others & & & 4 persons \\
\hline Household size & 62 & 77.5 & \\
\hline$-1-5$ & 18 & 22.5 & \\
\hline$-6-10$ & & & \\
\hline Level of education & 20 & 25.0 & \\
\hline- no formal education & 24 & 30.0 & \\
\hline- primary education & 29 & 36.2 & \\
\hline- secondary education & 7 & 8.8 & \\
\hline- tertiary education & & & \\
\hline Occupation & & 10.0 & \\
\hline- civil servant & 8 & 60.0 & \\
\hline- business/artisan & 48 & 28.8 & \\
\hline- farming & 23 & 1.2 & \\
\hline- missionary & 1 & & \\
\hline & & & \\
\hline
\end{tabular}

Source: own study.

household in Nigeria has an average of 6 children. The implication is that the more the people in the household, the likelihood that more people will be available to obtain water required for the household. Most $(60.0 \%)$ of the respondents engaged in businesses and farming while $28.8 \%$ while into farming. Many of them are into trading because of the closeness of to the Republic of Benin where they could obtain goods at a cheaper rate which can be sold to earn more income. Also, the artisan obtain needed materials for their business from the neighbouring countries.

\section{SOURCES OF WATER AVAILABLE FOR RURAL HOUSEHOLDS}

Table 2 shows the sources of water available in the study area. Most (97.5\%) of the rural households obtain their water from the few boreholes around because most well available did not have water, probably the well is not as deep as the borehole. Meanwhile, 90\% depend on the rainwater to obtain water for the household use and this is only possible during the raining season. For centuries people have relied on rainwater harvesting for households, landscape, livestock and agricultural uses [KELVIN, WARD 2006]. Water reservoir (86.2\%) was another major source of water available for the households in the study area. The implication is that many of the rural households aside borehole water, rely on the rainwater during wet season which is a short period and water is also harvested into the reservoirs during the wet season. The quantity of water stored in reservoirs will serve them during the dry season. 
Table 2. Sources of water available to rural households

\begin{tabular}{|l|c|c|}
\hline \multicolumn{1}{|c|}{ Variables } & Frequency (numbers) & Percentage \\
\hline Boreholes & 78 & 97.5 \\
\hline Piped-water & 1 & 1.2 \\
\hline Stream & 1 & 1.2 \\
\hline Rainwater & 72 & 90.0 \\
\hline Reservoir & 69 & 86.2 \\
\hline Hand pump & 11 & 13.8 \\
\hline
\end{tabular}

Source: own study.

The three major sources of water available in the study area which are boreholes, rainwater and reservoirs but are not sustainable because they directly or indirectly depend on certain factors. For example, the rain water and reservoirs depend on the weather condition which the rural households cannot predict and determine. AYENI et al. [2013] opined that the hydrologic impact of global warming contributes to the change in water balance parameters which increases or reduces water recharge and storage capacity. As a result, the capacity of surface water to supply water for the rural communities is degraded as rainfall reduces and ultimately surface water declines, water scarcity intensifies and ends in water insecurity in the communities.

Also, the borehole might need maintenance and electric power to operate the pumping machine which is not available in the study thereby making the borehole not functional. These main sources of water could not be effective and sustainable in their present state to solve the problem of water scarcity for livelihoods and domestic use in rural households. KRISHNA and HARI [2005] opined that water conservation and development of alternative water supplies have become necessary because surface and groundwater supplies will not be enough to meet future demand. The change in climate condition, to some extent, may have a significant impact on surface water availability. The increased temperature leads to an increase of evapotranspiration, thus reducing the recharge rate on a watershed scale and trigger more severe water depletion during the dry season [IPCC $2007 \mathrm{a}, \mathrm{b}$ ].

\section{ACCESSIBILITY OF THE WATER SOURCES AND ITS PROCUREMENT}

The distance and trekking time to the sources of water can affect the quantity of water will be available for the households use. Entries in Table 3 revealed that $50 \%$ of the households will trek between 100 to $100 \mathrm{~m}$ to obtain water from the borehole, and spent an average of $20 \mathrm{~min}$ for a trip to the borehole. Only $1.2 \%$ of the households obtain their water from tap water and stream with an average duration of 25 and $50 \mathrm{~min}$ respectively. The implication is that the sources of water are not close to the centre of the village and that could discourage the people from using the sources of water. This finding corroborate GRAHAM et al. [2016] report that in 24 sub-Saharan African countries estimated that $13.54 \mathrm{mln}$ adult women (and $3.36 \mathrm{mln}$ children), spend more than $30 \mathrm{~min}$ each day collecting water for their households. Also, GEERE et al. [2010] report that in a study of six communities in South Africa, women and children carried water weighing an average of $19.5 \mathrm{~kg}$ over an average distance of $335 \mathrm{~m}$. Sixty-nine per cent reported spinal pain, with the potential to lead to muscular-skeletal disorders. The tap water in the study area is not reliable because they did not flow all the time. It was observed that there was no major river and even the available stream dries up during the dry season. Most $(85 \%)$ of the rural households had access to the reservoir water within the distance of less than $100 \mathrm{~m}$ to their households. The available reservoir water depends on the volume of rainfall during the wet season. This implies that the available water in the reservoir is seasonal and it is determined by the amount of rainwater harvested which thereby determine the amount of water available for the households. The reservoir could be sited within the community or even at their respective homes. Rainwater harvesting systems may be installed and serviced in remote villages and may be constructed with local materials and local human power for low cost and efficient maintenance [No, WoN 2012].

Table 3. Distribution of rural households based on their access to different water sources

\begin{tabular}{|c|c|c|c|c|c|}
\hline \multirow[t]{2}{*}{ Specification } & $\begin{array}{l}\text { Bore- } \\
\text { hole }\end{array}$ & $\begin{array}{l}\text { Pipe } \\
\text { water }\end{array}$ & Stream & $\begin{array}{l}\text { Reser- } \\
\text { voir }\end{array}$ & $\begin{array}{l}\text { Hand } \\
\text { pump }\end{array}$ \\
\hline & \multicolumn{5}{|c|}{ cases number $(\%)$} \\
\hline \multicolumn{6}{|l|}{ Distance to water source } \\
\hline very far $(>1000 \mathrm{~m})$ & $\begin{array}{c}2 \\
(2.5)\end{array}$ & - & $\begin{array}{c}1 \\
(1.2)\end{array}$ & - & - \\
\hline far $(501-1000 \mathrm{~m})$ & $\begin{array}{c}19 \\
(23.8) \\
\end{array}$ & - & - & - & $\begin{array}{c}6 \\
(7.5)\end{array}$ \\
\hline moderately far $(101-500 \mathrm{~m})$ & $\begin{array}{c}21 \\
(26.2)\end{array}$ & $\begin{array}{c}1 \\
(1.2)\end{array}$ & - & $\begin{array}{c}1 \\
(1.2)\end{array}$ & $\begin{array}{c}5 \\
(6.2)\end{array}$ \\
\hline not far $(\leq 100 \mathrm{~m})$ & $\begin{array}{c}36 \\
(45.0) \\
\end{array}$ & - & - & $\begin{array}{c}68 \\
(85.0) \\
\end{array}$ & $\begin{array}{c}1 \\
(1.2) \\
\end{array}$ \\
\hline $\begin{array}{l}\text { households that do not use } \\
\text { identified water sources }\end{array}$ & $\begin{array}{c}2 \\
(2.5)\end{array}$ & $\begin{array}{c}79 \\
(98.8)\end{array}$ & $\begin{array}{c}79 \\
(98.8)\end{array}$ & $\begin{array}{c}11 \\
(13.8)\end{array}$ & $\begin{array}{c}68 \\
(85.0)\end{array}$ \\
\hline \multicolumn{6}{|l|}{$\begin{array}{l}\text { Duration to the water } \\
\text { sources (min) }\end{array}$} \\
\hline $1-15$ & $\begin{array}{c}35 \\
(43.9) \\
\end{array}$ & - & - & $\begin{array}{c}68 \\
(85.0) \\
\end{array}$ & $\begin{array}{c}3 \\
(3.8) \\
\end{array}$ \\
\hline $16-30$ & $\begin{array}{c}33 \\
(41.4) \\
\end{array}$ & $\begin{array}{c}1 \\
(1.3)\end{array}$ & - & $\begin{array}{c}1 \\
(1.2)\end{array}$ & $\begin{array}{c}3 \\
(3.8)\end{array}$ \\
\hline $31-45$ & $\begin{array}{c}10 \\
(12.7)\end{array}$ & - & - & - & $\begin{array}{c}6 \\
(7.7)\end{array}$ \\
\hline $46-60$ & - & - & $\begin{array}{c}1 \\
(1.3)\end{array}$ & - & - \\
\hline $\begin{array}{l}\text { Average minute spent to } \\
\text { the water sources }\end{array}$ & 19.35 & 25.00 & 50.00 & 2.68 & 24.17 \\
\hline
\end{tabular}

Source: own study.

\section{QUANTITY OF WATER USED IN HOUSEHOLDS PER DAY}

Figure 1 revealed that more than half $(51.90 \%)$ of the households used between 126 to 2751 of water per day, while only $7.6 \%$ of the households could obtain above 2751 of water for their use. The average water used by the households in the study area is 162.51 for domestic and livelihoods activities. These activities include washing, cooking, drinking and so on within the households and livelihoods sites. THOMPSON et al. [2001] opined that productive water which includes uses such as brewing, animal watering, construction and small-scale horticulture may be critical among the urban poor in sustaining livelihoods and 


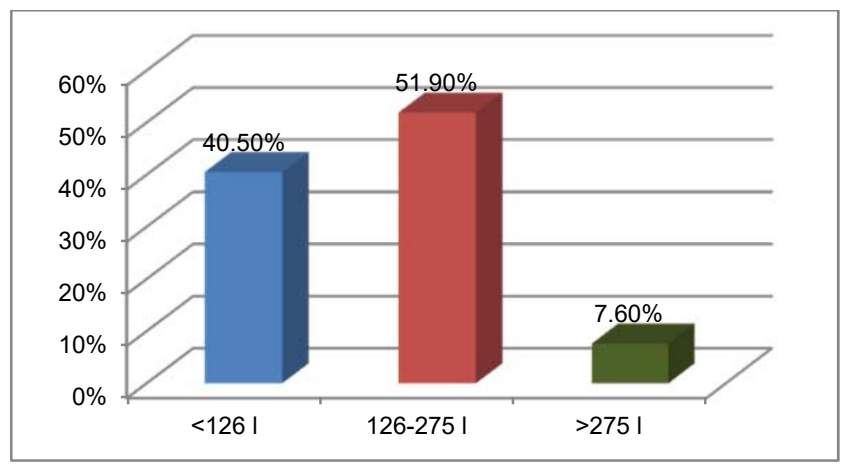

Fig. 1. Distribution of households based on the quantity of water used per day; source: own study

avoiding poverty and therefore has a considerable indirect influence on human health.

According to the World Health Organization WHO [2003], between 50 and 1001 of water per person per day is needed to ensure that most basic needs are met and few health concerns arise. In the study area, an individual has access to less than the required quantity of water which by the standard it will be enough to meet their basic need of water both for their domestic and livelihoods uses. The total water available for the households was far below the expectation, which implies that the water is not sufficient for the household's needs and it is an indication of water scarcity. The provision of 2001 of safe drinking water per household per day which is about 60001 per month was ordered to be minimum available water for the local households until they will have full access to the public water services to meet their basic needs [UN, OHCHR, UN-HABITAT, WHO 2010]. Even though households are expected to have adequate right to an abundance of water to be able to survive without any health risk and other vulnerabilities but the short of water have disposed them to several consequences which resulted from water scarcity. It is the right of the people to have access to adequate, clean and safe water for their uses both at home and livelihoods centres.

\section{WATER QUALITY ANALYSIS OF THE WATER SAMPLES FROM THE STUDY AREA}

The result of the laboratory analysis detailed in Table 4 revealed the physical and chemical properties of water samples obtained from selected water sources used in the study area. The $\mathrm{pH}$ values of all the water samples are within the range of 6.5 and 7.0, which is in line with the standard of WHO [2004], 6.5-8.5, making it suitable for domestic use. Electrical conductivity values reported from all the water sources were within $38-1,220 \mu \mathrm{S} \cdot \mathrm{cm}^{-1}$. This implies that the water samples are free from metallic substances as it is below the WHO standard. The result further revealed that the water samples were tasteless, colourless and odourless which indicates that the water samples met the convection standard of water characteristics. The result corroborates findings of AROH et al. [2013], OMOLADE and ZANAIB [2017] that the physical analysis of sachet water showed that all sampled brands were colourless, odourless and tasteless.
Table 4. Result of the water quality analysis in the study area

\begin{tabular}{|l|c|c|c|c|c|}
\hline \multicolumn{1}{|c|}{ Parameter } & Borehole & $\begin{array}{c}\text { Hand } \\
\text { pump }\end{array}$ & Stream & $\begin{array}{c}\text { Reser- } \\
\text { voir }\end{array}$ & $\begin{array}{c}\text { WHO } \\
\text { standard }\end{array}$ \\
\hline $\mathrm{pH}$ & 7.05 & 6.48 & 6.86 & 6.64 & $6.5-9.5$ \\
\hline$E C\left(\mu \mathrm{S} \cdot \mathrm{cm}^{-1}\right)$ & 610 & 910 & 193 & 40 & 1200 \\
\hline Nitrate $\left(\mathrm{mg} \cdot 1^{-1}\right)$ & 8.86 & 8.86 & 8.68 & 9.77 & $10-50$ \\
\hline Chlorine $\left(\mathrm{mg} \cdot 1^{-}\right)$ & 26.5 & 13.5 & 95 & 29 & 250 \\
\hline Magnesium $\left(\mathrm{mg} \cdot 1^{-}\right)$ & 114 & 100 & 40 & 62 & 50 \\
\hline Sulphate $\left(\mathrm{mg} \cdot 1^{-}\right)$ & 57 & 82 & 69 & 85 & 250 \\
\hline Iron $\left(\mathrm{mg} \cdot 1^{-}\right)$ & 4.28 & 4.33 & 4.30 & 2.12 & $0-3$ \\
\hline TDS & 0.3 & 0.45 & 97 & 20 & $\begin{array}{c}500- \\
1000\end{array}$ \\
\hline Taste & tasteless & tasteless & tasteless & tasteless & tasteless \\
\hline Colour & $\begin{array}{c}\text { colour- } \\
\text { less }\end{array}$ & $\begin{array}{c}\text { colour- } \\
\text { less }\end{array}$ & $\begin{array}{c}\text { colour- } \\
\text { less }\end{array}$ & $\begin{array}{c}\text { colour- } \\
\text { less }\end{array}$ & $\begin{array}{c}\text { colour- } \\
\text { less }\end{array}$ \\
\hline Odour & odour- & odour- & odour- & odour- & odour- \\
less & less & less & less \\
\hline Temperature $\left({ }^{\circ} \mathrm{C}\right)$ & 29.7 & 30 & 29.2 & 25 & $20-32$ \\
\hline Turbidity $(\mathrm{FTU})$ & 0.02 & 0.02 & 0.02 & 0.03 & 5 \\
\hline
\end{tabular}

Source: own study.

Moreso, the turbidity value was also within the WHO [2004] limit (5 NTU), this implies that the water samples have less sediment flow and does not require going through settling or filtration before it can be utilized. The total dissolved solids values indicate very low presence of inorganic salts (calcium, magnesium, potassium, sodium, bicarbonate, chlorides, and sulphates) and a small amount of organic matter in all the water samples. The implication of this is that water from these sources could be hard which will reduce the ability of the water to lather soap resulting in wastage of water resources. OREWOLE et al. [2007] opined that bitter, salty or brackish taste of water increases the corrosive ability of the water. Nitrates are the most highly oxidized form of nitrogen compounds; they are present in surface and groundwater because it is the end product of aerobic decomposition of organic and nitrogenous matter. The nitrates values of water samples from all sources of water were not within the WHO standard. In terms of contamination of drinking groundwater, the nitrate is the most problematic element, the highest levels generally result from the external discharges (leaching from agricultural land, leakage of wastewater collection networks) [BENRABAH et al. 2016].

This element often gets into the water from locally septic tanks, animal wastes, and discharges from car exhausts. The chlorine and sulphate concentration in the water were within the WHO [2004] standard of $250 \mathrm{mg} \cdot \mathrm{dm}^{3}$, the results reveal that sulphate concentration range from $57-85 \mathrm{mg} \cdot \mathrm{dm}^{3}$ and chlorine concentration range from $13.5-96 \mathrm{mg} \cdot \mathrm{dm}^{3}$, which makes it good for consumption. SCHARDT [2000] asserted that excessive intake of drinkingwater containing sodium chloride at a concentration above $250 \mathrm{mg} \cdot \mathrm{dm}^{3}$ has been reported to produce hypertension. Chlorides in drinking water usually create taste and odour problems at concentrations [NAPGAL et al. 2003; SIEGEL 2007]. Chloride is a good conservative element to use for quality assurance in a mass balance model because no natural biological or chemical processes remove or add chloride to the surface water [BOUSLAH et al. 2017].

However, the water samples from the borehole, hand pump and stream had values exceeding the WHO limit for 
iron which is $0-3 \mathrm{mg} \cdot \mathrm{dm}^{3}$, these values make the water unsafe for consumption. The water that has a higher concentration of iron in them could lead to the formation of goiter in adults. Also, a high concentration of magnesium was recorded in all the water samples except borehole and stream which is above the WHO [2004] limit of $50 \mathrm{mg} \cdot \mathrm{dm}^{3}$ make it unsafe for consumption. The essence of the water analysis is to confirm whether parameters of the water sampled from the study area deviate from WHO [2004] standards for potable water. OSUJI and ABIASO [2014] asserted that there is a need to make efforts which will aid correction of deviation of the water from the standard so as to obtain safe water the will use useful for the people.

\section{USAGE OF AVAILABLE WATER IN THE STUDY AREA}

Water is used for many purposes in the households, the uses vary from drinking to washing, cooking, irrigating, building and so on. Table 5 revealed the major uses of water by the households in the study area which include sanitation, cooking, and domestic chores with the means above 4.0 while the use of water for commercial purposes had a mean of 3.05. This implication is that water is mainly used for domestic and commercial purposes among other purposes in the study area. This result concurs with the finding of International Food Policy Research Institute [ROSEGRANT et al. 2002] that reports that productive water use activities that water is essential for drinking and household use and for food production. BiswAS [2004] opined that water is used for domestic, agricultural, industrial, and recreational and hydropower generation.

Table 5. Level of water utilization among the rural households in the study area

\begin{tabular}{|l|c|c|c|c|c|c|}
\hline \multirow{2}{*}{ Utilization kind } & Always & Often & $\begin{array}{c}\text { Some- } \\
\text { times }\end{array}$ & Rarely & Never & $\begin{array}{l}\text { Mean } \\
\text { score }\end{array}$ \\
\cline { 2 - 6 } Sanitation & $\begin{array}{c}70 \\
(87.5)\end{array}$ & $\begin{array}{c}7 \\
(8.8)\end{array}$ & $\begin{array}{c}3 \\
(3.8)\end{array}$ & - & - & 4.84 \\
\hline Cooking & $\begin{array}{c}61 \\
(76.2)\end{array}$ & $\begin{array}{c}3 \\
(3.8)\end{array}$ & $\begin{array}{c}12 \\
(15.0)\end{array}$ & $\begin{array}{c}4 \\
(5.0)\end{array}$ & - & 4.51 \\
\hline $\begin{array}{l}\text { Domestic } \\
\text { chores }\end{array}$ & $\begin{array}{c}55 \\
(68.8)\end{array}$ & $\begin{array}{c}10 \\
(12.5)\end{array}$ & $\begin{array}{c}13 \\
(16.2)\end{array}$ & $\begin{array}{c}2 \\
(2.5)\end{array}$ & - & 4.48 \\
\hline Commercial & $\begin{array}{c}10 \\
(12.5)\end{array}$ & $\begin{array}{c}19 \\
(23.8)\end{array}$ & $\begin{array}{c}23 \\
(28.8)\end{array}$ & $\begin{array}{c}21 \\
(26.2)\end{array}$ & $\begin{array}{c}7 \\
(8.8)\end{array}$ & 3.05 \\
\hline $\begin{array}{l}\text { Religion and } \\
\text { cultural }\end{array}$ & $\begin{array}{c}13 \\
(16.2)\end{array}$ & $\begin{array}{c}8 \\
(10.0)\end{array}$ & $\begin{array}{c}21 \\
(26.2)\end{array}$ & $\begin{array}{c}19 \\
(23.8)\end{array}$ & $\begin{array}{c}19 \\
(23.8)\end{array}$ & 2.71 \\
\hline $\begin{array}{l}\text { Wetting and } \\
\text { cultivation }\end{array}$ & $\begin{array}{c}15 \\
(18.8)\end{array}$ & $\begin{array}{c}14 \\
(17.5)\end{array}$ & $\begin{array}{c}8 \\
(10.0)\end{array}$ & $\begin{array}{c}16 \\
(20.0)\end{array}$ & $\begin{array}{c}27 \\
(33.8)\end{array}$ & 2.68 \\
\hline Irrigation & $\begin{array}{c}8 \\
(10.0)\end{array}$ & $\begin{array}{c}12 \\
(15.0)\end{array}$ & $\begin{array}{c}7 \\
(8.8)\end{array}$ & $\begin{array}{c}21 \\
(26.2)\end{array}$ & $\begin{array}{c}32 \\
(40.0)\end{array}$ & 2.29 \\
\hline Petty trading & $\begin{array}{c}3 \\
(3.8)\end{array}$ & $\begin{array}{c}9 \\
(11.2)\end{array}$ & $\begin{array}{c}7 \\
(8.8)\end{array}$ & $\begin{array}{c}22 \\
(27.5)\end{array}$ & $\begin{array}{c}39 \\
(48.8)\end{array}$ & 1.94 \\
\hline Dairy farming & $\begin{array}{c}5 \\
(6.2)\end{array}$ & $\begin{array}{c}2 \\
(2.5)\end{array}$ & $\begin{array}{c}11 \\
(13.8)\end{array}$ & $\begin{array}{c}15 \\
(18.8)\end{array}$ & $\begin{array}{c}47 \\
(58.8)\end{array}$ & 1.79 \\
\hline Building & $\begin{array}{c}3 \\
(3.8)\end{array}$ & $\begin{array}{c}2 \\
(2.5)\end{array}$ & $\begin{array}{c}6 \\
(7.5)\end{array}$ & $\begin{array}{c}8 \\
(10.0)\end{array}$ & $\begin{array}{c}61 \\
(76.2)\end{array}$ & 1.48 \\
\hline
\end{tabular}

Source: own study.

The use of water for wetting and cultivation as well as irrigation had a mean of less than 3.0, this is an indication of water scarcity because if the water has been in abundance its level of use in cultivation and irrigation could have been higher. The community commitment to sustainable water resources management is crucial in water security. The people are willing to participate and cooperate in supporting activities that can improve water management to tackle the scarcity of water [KUNTIYAWICHAI et al. 2017]. The main factors that could limit the future food production is water, improper utilization of water for agriculture in the face of water scarcity which could lead to low food production [ROSEGRANT et al. 2002]. The projected increase of the world population growth rate suggests that higher food demand is expected in the future, with a direct effect on agricultural water usage. Water availability and accessibility are the most significant constraining factors for crop production, addressing this issue is indispensable for areas affected by water scarcity [JIMÉNEZ et al. 2014; MANCOSU et al. 2015; UNDESAPD 2013].

\section{CAUSES OF WATER SCARCITY IN THE STUDY AREA}

Entries in Table 6 revealed that more than $90 \%$ of the households in the study area indicated that increased sunlight intensity, insufficient rainfall, pollution of water sources and population increase were the major causes of water scarcity. The intensity of sunlight and drop in the volume of rainfall the two which are elements of climate contribute to the dryness of the rivers and level of water in the well and reservoirs. This strengthened the shortage of water and increases the threat of water scarcity in most rural areas. FAO [2012a] posited that climate change is expected to alter hydrological regimes and the availability of freshwater. The indication is that the effect of climate change might have an influence on the variation in the volume of rainfall thereby affecting the supply of water in the area. The irregularity of rainfall affects the main livelihood of the rural communities which is farming. OMOTAYO [2010] opined that rainfall as a source of water for agriculture is not reliable year round.

Table 6. Causes of water scarcity identified by households in the study area

\begin{tabular}{|l|c|c|}
\hline \multicolumn{1}{|c|}{ Parameter } & $\begin{array}{c}\text { Frequency - } \\
\text { cases number }\end{array}$ & Percentage \\
\hline Increase in sunlight intensity & 78 & 97.5 \\
\hline Insufficient rainfall & 78 & 97.5 \\
\hline Pollution of water sources & 76 & 95.0 \\
\hline Population increase & 75 & 93.8 \\
\hline Inadequate water sources & 69 & 86.3 \\
\hline Quick dryness of the water sources & 65 & 81.3 \\
\hline Change in land use & 49 & 61.3 \\
\hline
\end{tabular}

Source: own study.

The water sources in the study area are very few, even the available ones are polluted and this makes the polluted water sources not to be useful for the domestics and livelihoods purpose of the people. As the population of the area is increasing, the people demand water both for their lives and livelihoods is also increasing, thereby increases the pressure on the limited water sources. Due to the population pressure, the water scarcity increase as the demand for water increases. As estimated by ROETTER and VAN KEULEN [2008], the median population growth projection for 
2025 is between is 8.3 and $7.3 \mathrm{bln}$, compared with the present 6.4 bln, with an annual growth rate of approximately $1 \%$ between now and 2025 in Asia, where the population will grow by $650 \mathrm{mln}$ people. At present, nearly $80 \%$ of the world's population is exposed to high levels of threat to water security [VÖRÖSMARTY et al. 2010], and the increase of world population will have a significant impact on water usage for food.

\section{PERCEIVED EFFECT OF WATER SCARCITY ON LIVELIHOOD ACTIVITIES}

Water scarcity has several effects on the people and one of the aspects of their lives affected by the scarcity of water is their livelihood activities. The perceived effect of the water scarcity on the livelihood activities of the people in the study area was obtained and presented in Table 7. Results show that the respondents strongly agreed that water scarcity affects the quantity of available water for their fish farming (mean $=4.84$ ) determine the kind of crops cultivated (mean $=4.81$ ) and farming system practised $($ mean $=4.74)$ in the study area. KIJNE [2001] suggests that the cropping pattern and water demanding are important for crops like rice and sugarcane among others. The complex interdependencies between water resources and food production have been referred to in recent studies as an evolving global food crisis [HIGHTOWER, PIERCE 2008; LUNDQVIST et al. 2008]. Many (65\%) of the respondents strongly agreed that they spend more money in acquiring enough water for their livelihood activities, while $43.8 \%$ also concurred that water scarcity reduces the quantity of the products that can be produced per time. People need water to carry out a wide spread activities which are essential to their livelihoods. Water plays an important role in people's livelihoods. The discrepancy between the needs of people and the design and management of water services leads to a number of problems [SMITs 2005].

Furthermore, the respondents agreed that getting enough water for livelihoods is stressful and it affects performance in their livelihood activities (mean $=4.20)$, that all morning was spent in looking for water which affects the time they arrive at livelihood centres $($ mean $=4.08)$ and lack of water for their livelihoods can affect profits (mean =4.46). The implication is that time and efforts that were used to collect water can influence the arrival to livelihood centre, performance at work during to the stress undergo during the collecting of water and thereby affecting the profits. MORIARTY and BUTTERWORTH [2003] opined that time and effort spent collecting water during water scarcity can be reduced with an improved water supply and this time can be put to other activities. Table 8 however, revealed that $57.7 \%$ of the respondents had the favourable perception which implies that water scarcity has a negative effect on their livelihoods and the consequences of it could eventually put immense pressure on available limited water for domestic use. HOPE et al. [2003] found that the betteroff in a village in South Africa were actually the ones with best access to water supply and hence in a better position to get the full benefits of this water and that improved water supply has the potential to have a positive impact on a number of aspects of people's livelihoods.
Table 7. Perceived effect of water scarcity on livelihoods in the study area

\begin{tabular}{|c|c|c|c|c|c|c|}
\hline \multirow{2}{*}{ Perception statements } & SA & $\mathrm{A}$ & $\mathrm{U}$ & $\mathrm{D}$ & SD & \multirow{2}{*}{$\begin{array}{l}\text { Mean } \\
\text { score }\end{array}$} \\
\hline & \multicolumn{5}{|c|}{ cases number $(\%)$} & \\
\hline $\begin{array}{l}\text { I spend more money in } \\
\text { acquiring enough water } \\
\text { for my livelihood activi- } \\
\text { ties }\end{array}$ & $\begin{array}{c}52 \\
(65.0)\end{array}$ & $\begin{array}{c}22 \\
(27.5)\end{array}$ & - & $\begin{array}{c}3 \\
(3.8)\end{array}$ & $\begin{array}{c}3 \\
(3.8)\end{array}$ & 4.46 \\
\hline $\begin{array}{l}\text { I change my source of } \\
\text { income from time to time } \\
\text { due to an insufficient } \\
\text { supply of water }\end{array}$ & $\begin{array}{c}16 \\
(20.0)\end{array}$ & $\begin{array}{c}22 \\
(27.5)\end{array}$ & $\begin{array}{c}2 \\
(2.5)\end{array}$ & $\begin{array}{c}21 \\
(26.2)\end{array}$ & $\begin{array}{c}19 \\
(23.8)\end{array}$ & 2.94 \\
\hline $\begin{array}{l}\text { Water scarcity reduces the } \\
\text { amount of product I can } \\
\text { produce per time }\end{array}$ & $\begin{array}{c}35 \\
(43.8)\end{array}$ & $\begin{array}{c}20 \\
(25.2)\end{array}$ & $\begin{array}{c}9 \\
(11.2)\end{array}$ & $\begin{array}{c}8 \\
(10.0)\end{array}$ & $\begin{array}{c}8 \\
(10.0)\end{array}$ & 3.82 \\
\hline $\begin{array}{l}\text { Water scarcity determines } \\
\text { the farming system prac- } \\
\text { tised in my community }\end{array}$ & $\begin{array}{c}63 \\
(78.8)\end{array}$ & $\begin{array}{c}15 \\
(18.8)\end{array}$ & $\begin{array}{c}1 \\
(1.2)\end{array}$ & - & $\begin{array}{c}1 \\
(1.2)\end{array}$ & 4.74 \\
\hline $\begin{array}{l}\text { Water availability is one } \\
\text { of the factors that deter- } \\
\text { mine the kind of crops } \\
\text { cultivated in my commu- } \\
\text { nity }\end{array}$ & $\begin{array}{c}68 \\
(85)\end{array}$ & $\begin{array}{c}11 \\
(13.8)\end{array}$ & - & - & $\begin{array}{c}1 \\
(1.2)\end{array}$ & 4.81 \\
\hline $\begin{array}{l}\text { The stress in getting } \\
\text { enough water affects the } \\
\text { way I perform at my live- } \\
\text { lihood centre. }\end{array}$ & $\begin{array}{c}35 \\
(43.8)\end{array}$ & $\begin{array}{c}35 \\
(43.8)\end{array}$ & $\begin{array}{c}3 \\
(3.8)\end{array}$ & $\begin{array}{c}5 \\
(6.2)\end{array}$ & $\begin{array}{c}2 \\
(2.5)\end{array}$ & 4.20 \\
\hline $\begin{array}{l}\text { Lack of water increases } \\
\text { the profit I earn from my } \\
\text { livelihood }\end{array}$ & $\begin{array}{c}3 \\
(3.8)\end{array}$ & - & $\begin{array}{c}7 \\
(8.8)\end{array}$ & $\begin{array}{c}17 \\
(21.2)\end{array}$ & $\begin{array}{c}53 \\
(66.2)\end{array}$ & 4.46 \\
\hline $\begin{array}{l}\text { Poor access to water dis- } \\
\text { courages customers from } \\
\text { patronizing my livelihood } \\
\text { centre }\end{array}$ & $\begin{array}{c}6 \\
(7.5)\end{array}$ & $\begin{array}{c}9 \\
(11.5)\end{array}$ & $\begin{array}{c}10 \\
(12.5)\end{array}$ & $\begin{array}{c}18 \\
(22.5)\end{array}$ & $\begin{array}{c}37 \\
(46.2)\end{array}$ & 3.89 \\
\hline $\begin{array}{l}\text { Water scarcity does not } \\
\text { affect the quality of prod- } \\
\text { uct I produce }\end{array}$ & $\begin{array}{c}11 \\
(13.8)\end{array}$ & $\begin{array}{c}3 \\
(3.8)\end{array}$ & $\begin{array}{c}14 \\
(17.5)\end{array}$ & $\begin{array}{c}15 \\
(18.8)\end{array}$ & $\begin{array}{c}37 \\
(46.2)\end{array}$ & 3.80 \\
\hline $\begin{array}{l}\text { When I spend all morning } \\
\text { looking for water it will } \\
\text { not affects the time I ar- } \\
\text { rive at my livelihood cen- } \\
\text { tre }\end{array}$ & $\begin{array}{c}7 \\
(8.8)\end{array}$ & $\begin{array}{c}4 \\
(5)\end{array}$ & $\begin{array}{c}2 \\
(2.5)\end{array}$ & $\begin{array}{c}30 \\
(37.5)\end{array}$ & $\begin{array}{c}37 \\
(46.2)\end{array}$ & 4.08 \\
\hline $\begin{array}{l}\text { The cleaning of the liveli- } \\
\text { hood centre depends on } \\
\text { the availability of water }\end{array}$ & $\begin{array}{c}28 \\
(35)\end{array}$ & $\begin{array}{c}18 \\
(22.5)\end{array}$ & $\begin{array}{c}2 \\
(2.5)\end{array}$ & $\begin{array}{c}20 \\
(25)\end{array}$ & $\begin{array}{c}12 \\
(15)\end{array}$ & 2.62 \\
\hline $\begin{array}{l}\text { Availability of water does } \\
\text { not affect fish farming }\end{array}$ & - & $\begin{array}{c}2 \\
(2.5)\end{array}$ & $\begin{array}{c}1 \\
(1.2)\end{array}$ & $\begin{array}{c}5 \\
(6.2)\end{array}$ & $\begin{array}{c}72 \\
(90)\end{array}$ & 4.84 \\
\hline
\end{tabular}

Source: own study.

Table 9. Distribution of based on aggregate perceived effect of water scarcity

\begin{tabular}{|l|c|c|}
\hline \multicolumn{1}{|c|}{ Perception } & $\begin{array}{c}\text { Frequency - } \\
\text { cases number }\end{array}$ & Percentage \\
\hline Favourable perception (positive) & 34 & 42.3 \\
\hline Unfavourable perception (negative) & 46 & 57.7 \\
\hline
\end{tabular}

Source: own study.

\section{TESTING OF HYPOTHESIS}

The result of hypothesis reveals that there is a significant relationship between usage of water $(r=0.370)$ and the perceived effect of water scarcity on livelihoods at level of significant level of $p<0.01$. This implies that the rate at which water was used by the rural households on different domestic and livelihoods activities could affect their opinion on how the water scarcity affects their activities especially livelihoods. The higher the quantity of water 
used by rural households especially during the water scarcity the more likely that they will have an unfavourable perception of the effect of water scarcity on the livelihoods. Shortage of water supply may restrict respondents from carrying out some livelihood activities which are affected by water supply directly and those livelihoods affected indirectly are not exempted from the effect of water scarcity.

\section{CONCLUSIONS}

The study concluded that rural households perceived a negative effect of the water scarcity largely in their livelihood as a result of an increase in expenses in acquiring water, energy and time consumed in order to obtain it, and inability to meet the required available water for their livelihoods. Climate-related factors such as insufficient rainfall and high sunlight intensity were stated as the cause of water scarcity while pollution of the water sources cannot be ignored. The available water for households in the study area is not adequate and contain some elements which are not of the World Health Organization standard for good potable water. The result of water quality analysis established that the available water is not safe for drinking but can be useful for other purposes. It is therefore recommended that the government and NGOs should provide more water infrastructures and increase the supply of safe water in order to generate a wide range of potential benefits to individuals, households, and communities. Households should endeavours to purify their water before consumption and also conserve water to have enough during scarcity. The community could also monitor the activities of the people around the conserved water facilities to prevent pollution and wastage of water to be able to tackle water scarcity in rural communities.

\section{REFERENCES}

Aroh K.N., Eze E.M., Ukaji D., Wachuku C.K., Gobo A.E., AbBe S.D., Teme S.C., IGONI A.H. 2013. Health and environmental components of sachet water consumption and trade in Aba and Port Harcourt, Nigeria. Journal of Chemical Engineering and Materials Science. Vol. 4. Iss. 2 p. 13-22.

Ayeni A.O., Soneye A.S.O., BAdRU F.A. 2013. Adaptation to water stress and climate change in Nigeria: The indigenous knowledge and socio-cultural nexus of humanitarian services and crisis management. [4th annual Production and Operation Management Society (POMS) Conference] [3-6.05.2013 Denver, Colorado, USA].

BARRETO C. 2008. Small scale solar powered drip irrigation [online]. M.Sc. Thesis. Lowell University of Massachusetts. [Access 06.02.2016]. Available at: http://faculty.uml.edu/ spennell/Teaching/EngineeringDE/SolarDripMasterThesis BarretoFinal.pdf

Benrabah S., Attoui B., Hannouche M. 2016. Characterization of groundwater quality destined for drinking water supply of Khenchela City (eastern Algeria). Journal of Water and Land Development. No. 30 p. 13-20. DOI 10.1515/jwld2016-0016.

BHARUCHA E. 2005. Textbook of environmental studies for undergraduate courses. Hyderabad. University Press Private. ISBN 9788173715402 pp. 192.
BISWAS A.K. 2004. Integrated water resources management: A reassessment: A water forum contribution. Water International. Vol. 29. Iss. 2 p. 248-256.

Bouslah S., DJemili L., Houichi L. 2017. Water quality index assessment of Koudiat Medouar Reservoir, northeast Algeria using weighted arithmetic index method. Journal of Water and Land Development. No. 35 p. 221-228. DOI 10.1515/ jwld-2017-0087.

ELSON D. 2012. Review of world development report 2012: Gender equality and development. Global social policy. An Interdisciplinary Journal of Public Policy and Social Development. Vol. 12. Iss. 2 p. 178-183.

FAO 2012a. Aquastat database [online]. Rome. Food and Agriculture Organization of the United Nations. [Access 20.11. 2018]. Available at http://www.fao.org/nr/aquastat

FAO 2012b. Coping with water scarcity: An action framework for agriculture and food security. FAO Water Reports. No. 38. Rome. Food and Agriculture Organization of the United Nations pp. 78.

Geere J.A.L., Hunter P.R., Jagals P. 2010. Domestic water carrying and its implications health: A review and mixed methods pilot study in Limpopo Province, South Africa. Environmental Health. Vol. 9. Iss. 52 p. 1-13.

Gholamrezai S., Sepahvand F. 2017. Farmers' participation in Water User Association in western Iran. Journal of Water and Land Development. No. 35 p. 49-56. DOI 10.1515/jwld2017-0067.

Graham J.P., Mitsuaki H., Seung-Sup K. 2016. An analysis of water collection labor among women and children in 24 SubSaharan African Countries. PLoS ONE. Vol. 11. Iss. 6 e0155981. DOI 10.1371/journal.pone.0155981.

Grant S.B., Saphores J.D., Feldman D.L., Hamilton A.J., Fletcher T.D., CoOK P.L.M., ... MARUSIC I. 2012. Taking the "waste" out of "wastewater" for human water security and ecosystem sustainability. Science. Vol. 337. Iss. 6095 p. $681-$ 686.

Hightower M., PierCe S.A. 2008. The energy challenge. Nature. Vol. 452 p. $285-286$.

Hope R.A., DiXon P.J., von Maltitz G. 2003. The role of improved domestic water supply in livelihoods and poverty reduction in Limpopo province, South Africa. In: Water, poverty and the productive uses of water at the household level: Practical experiences, new research and policy implications from innovative approaches to the provision and use of household water supplies. Eds. J. Butterworth, P. Moriarty, B. van Koppen. Proceedings of an international symposium. 21-23.01.2003 Johannesburg, South Africa. Delft, The Netherlands. IRC. Available at: www.irc.nl/page/6129

IPCC 2007a. Climate change 2007: Synthesis report. Contribution of working group to the fourth assessment report of the Intergovernmental Panel on Climate Change. Cambridge, UK. Cambridge University Press. ISBN 978-0-521-88011-4 hardback pp. 851.

IPCC 2007b. Climate change 2007: The physical science basis. Contribution of working group I to the fourth assessment report of the Intergovernmental Panel on Climate Change. Cambridge, UK. Cambridge University Press. ISBN 978-0521-8809-1 pp. 996.

IRIN 2007. Global: More extreme weather in poorer countries [online]. Integrated Regional Information Networks. [Access 23.05.2018]. Available at: https://www.thenewhumanitarian. org

Jiménez Cisneros B.E., Oki T., Arnell N.W., Benito G., Cogley J.G., Döll P., Jiang T., Mwakalila S.S. 2014. Freshwater resources. In: Climate change 2014: Impacts, adaptation, and vulnerability. Part A. Global and sectoral aspects. Contribution of Working Group II to the Fifth Assess- 
ment Report of the Intergovernmental Panel on Climate Change. Eds. C.B. Field, V.R. Barros, D.J. Dokken, K.J. Mach, M.D. Mastrandrea, T.E. Bilir, M. Chatterjee, K.L. Ebi, Y.O. Estrada, R.C. Genova. Cambridge, UK, New York, NY, USA. Cambridge University Press p. 229-269.

KELVIN J., WARD E.A. 2006. Rain water harvesting Texas water development board [online]. [Access 27.11.2018]. Available at: http://www.tx.us/homeindex.asp

KIJNE J.W. 2001. Lessons learned from the change from supply to demand water management in irrigated agriculture: A case study from Pakistan. Water Policy. Vol. 3 p. 109-123.

KREBS M. 2010. Nigeria reports water scarcity across numerous states [online]. Digital Journal. [Access 04.06.2018]. Available at: http://www.digitaljournal.com/article/301656

KRISHNA H. J. 2005. The success of rainwater harvesting in Texas [online]. The Texas Manual on Rainwater Harvesting. 3rd ed. Austin, Texas. Texas Water Development Board. [Access 07.01.2019]. Available at http://www.twdb.texas.gov/ publications/brochures/conservation/doc/Rainwater HarvestingManual_3rdedition. pdf

KunTIYAWICHAi K., DAU Q.V., INTHAVONG S. 2017. Community engagement for irrigation water management in Lao PDR. Journal of Water and Land Development. No. 35 p. 121-128. DOI 10.1515/jwld-2017-0075.

Lundqvist J., de Fraiture C., Molden D., Berndes G., Berntell A., Falkenmark M., Holmen H., Karlberg L. LaNNERSTAD M. 2008. Saving water: From field to fork - curbing losses and wastage in the food chain. SIWI Policy Brief. Stockholm. SIWI pp. 35.

MAFINISEBI T.E. 2002. Rural infrastructure and poverty reduction in Nigeria. In: Poverty reduction and the Nigeria agricultural sector: A book of readings. Ed. F. Okunmadewa. Ibadan, Elshaddai Global Ventures Ltd. p. 91-109.

Mancosu N., Snyder R.L., Kyriakakis G., Spano D. 2015. Water scarcity and future challenges for food production. Water. Vol. 7 p. 975-992.

Moriarty P., ButTerworth J. 2003. The productive use of domestic water supplies: How water supplies can play a wider role in livelihood improvement and poverty reduction. Thematic Overview Paper. [online] Netherlands. [Access 15.01.2019]. Available at: https://www.musgroup.net/sites/ default/files/livelihood.pdf

MutA'AHellandendu J. 2012. Health implications of water scarcity in Nigeria. European Scientific Journal. Vol. 8. Iss. 18 p. 111-117.

NAPGAL N.K., LeVy D.A., MacDonald D.D. 2003. Ambient water quality guidelines for chloride. Overview Report. British Columbia. Water, Air and Climate Change Branch. Available at: https://pdfs.semanticscholar.org/55f6/e21efd $43 \mathrm{~d} 480$ cce240752cf5e06197f63203.pdf

No K., WON T. 2012. Rainwater harvesting in Pacific islands. [3rd IWA International Conference on Rainwater Harvesting and Management]. [20-24.05 2012 Goseong, Korea].

NPC 2006. National population appraisal. Ogun State Division [online]. National Population Commission [Access 16.09.2019]. Available at: https://www.citypopulation.de/ php/nigeria-admin.php?admlid=NGA028

OHCHR, UN-HABITAT, WHO 2010. The Right to Water [online]. Fact Sheet. No. 35. United Nations, Office of the High Commissioner for Human Rights (OHCHR), United Nations Human Settlements Programme (UN-HABITAT), World Health Organization (WHO). [Access 27.11.2018]. Available at http://www.ohchr.org/Documents/Publications/ FactSheet35en.pdf

OMOLADE O.O., ZANAIB G.O. 2017. Parasitological evaluation of sachet drinking water in areas of Lagos State, Nigeria. Electronic Journal of Biology. Vol. 13. Iss. 2 p. 144-151.
OмотAyo A.M. 2010. The Nigerian farmer and the elusive crown. 30th Inaugural Lecture. Abeokuta, Nigeria. University of Agriculture p. 4-52.

Orewole M.O., Makinde O.W., Adekalu K.O., Shittu K.A. 2007. Chemical examination of piped water supply of Ile-Ife in Southwest Nigeria. Journal of Environmental Health Science and Engineering. Vol. 4. Iss. 1 p. 51-56.

OrR S., Pegram G. 2014. Business strategy for water challenges: From risk to opportunity. Saltaire, United Kingdom. Greenleaf Publishing. ISBN 978-1910174272 pp. 84.

OSUJI S.C., ABIASO N.M. 2014. Water pollution and its control in the context of physical planning - a case study of selected water bodies in Owerri. International Journal for Education and Research. Vol. 2. Iss. 4 p. 86-92.

OtUFALE G.A., Coster A.S. 2012. Impact of water scarcity and drudgery of water collection on women' health in Ogun of Nigeria. Journal of Human Ecology. Vol. 39. Iss. 1 p. 1-9.

RoetTer R.P., van KeUlen H. 2008. Food security. In: Science for agriculture and rural development in low-income countries. Eds. R. Roetter, H. van Keulen, M. Kuiper, J. Verhagen, H.H. van Laar. The Netherlands. Springer p. 27-56.

Rosegrant M.W., Ximing C., Cline S. A. 2002. World water and food to 2025 dealing with scarcity. Washington. International Food Policy Research Institute. ISBN 0-89629-646-6 pp. 322.

SCHARDT D. 2000. Water, water everywhere [online]. Washington, D.C. Center for Science in the Public Interest. [Access 26.10.10]. Available at: https://www.questia.com/magazine/ 1G1-62494966/water-water-everywhere

SIEGEL L. 2007. Hazard identification for human and ecological effects of sodium chloride road salt. NH Department of Environmental Services pp. 15.

SMit R. 2002. The changing role of the husband/father in the dual-earner family in South Africa. Journal of Comparative Family Studies. Vol. 33 p. 401-415.

SMiTs S. 2005. Well Factsheet: Water and livelihoods [online]. [Access 20.10.2018]. Available at: http://www.Iboro.ac.uk/ wellresources/fact-sheets-htm/water\%20and\%20live.htm

Thompson J., Porras I.T., Tumwine J.K., Mujwahuzi M.R., Katuikatua M., Johnstone N., WoOd L. 2001. Drawers of water II: 30 years of change in domestic water use and environmental health in East Africa. Summary. London. International Institute for Environment and Development. ISBN 1904035981 pp. 116.

UN WWAP 2003. The world water development report 1: Water for people, water for life. United Nations World Water Assessment Programme. Executive summary. Paris, France. UNESCO pp. 36.

UNDESAPD 2013. World population prospects: The 2012 revision. Vol. II. Demographic Profiles (ST/ESA/SER.A/345). United Nations Department of Economic and Social Affairs, Population Division USA pp. 844.

Vörösmarty C.J., Mcintyre P.B., Gessner M.O., Dudgeon D., Prusevich A., Green P., Glidden S., Bunn S.E., SulliVAN C.A., LIERMANN C.R., DAVIES P.M. 2010. Global threats to human water security and river biodiversity. Science. Vol. 467 p. $555-561$.

WHO 2003. The world health report 2003: Shaping the future. Geneva. World Health Organization. ISBN 9241562439 pp. 193.

WHO 2004. Guidelines for drinking water quality: Incorporating first and second addenda. Vol. 1. Recommendations. 3rd ed. Geneva. World Health Organization. ISBN 978924154761 1 pp. 515. 


\title{
Adetayo K. AROMOLARAN, Ibiyinka O. ADEMILUYI, Abiodun E. SOTOLA, Felicia I. WOLE-ALO, Oluwadamilola A. AROMIWURA, Olubukola E. OGUNSUYI
}

\author{
Wpływ deficytu wody na poziom życia w gospodarstwach domowych na obszarze Iwoye-Ketu \\ w nigeryjskim stanie Ogun
}

\section{STRESZCZENIE}

Woda jest podstawowym dobrem, które wpływa na życie i warunki życia na świecie. W przedstawionej pracy badano wpływ deficytu wody na poziom życia w Iwoye-Ketu w stanie Ogun. Do badań losowo wybrano 80 wiejskich gospodarstw i próby wody. Zebrane dane analizowano za pomocą metod opisowych, wnioskowania i metod laboratoryjnych. Średni wiek respondentów wynosił 38 lat, a średnia wielkość gospodarstwa - 4 osoby. Głównym źródłem wody były studnie wiercone $(97,5 \%)$ i opady deszczu $(90,0 \%)$. Średni czas dojścia do źródła wody wynosił 24 minuty, a gospodarstwa zużywały średnio $162 \mathrm{dm}^{3}$ wody na dzień. Woda miała pH 6,87, sumę substancji rozpuszczonych $0,175 \mathrm{~g} \cdot \mathrm{dm}^{-3}$, temperaturę $^{-1}$ $29,9^{\circ} \mathrm{C}$ i mętność 0,6 FTU. Do głównych przyczyn niedostatku wody zaliczano niewystarczające opady $(97,5 \%)$, silne nasłonecznienie (97,5\%), zanieczyszczenie źródeł wody $(95,0 \%)$ i przeludnienie $(93,8 \%)$. Około 60\% respondentów uważało, że niedostatek wody wywiera ujemny wpływ na ich poziom życia. Analiza korelacji wykazała, że istnieje istotna zależność $(r=0,370, p<0,01)$ między zużyciem wody a odczuciem negatywnego wpływu jej braku. Stwierdzono, że woda jest dostępna gospodarstwom w niedostatecznej ilości i choć bezpieczna, to zawiera pewne składniki, które nie spełniają norm Światowej Organizacji Zdrowia ustalonych dla wody pitnej. Zaleca się, aby lokalna społeczność zbudowała miejsce gromadzenia i dystrybucji wody blisko centrum wsi, a rząd powinien zapewnić infrastrukturę w celu poprawy zaopatrzenia w wodę pitną.

Słowa kluczowe: analiza jakości wody, deficyt wody, Iwoye-Ketu, odczuwane skutki, poziom życia, źródła wody 